\title{
Eroding the Middle Ground: The Shift in Foreign Policy Underpinning South African Nuclear Diplomacy
}

\author{
RIAN LEITH* AND JOELIEN PRETORIUS**
}

\begin{abstract}
In international relations states labelled as 'middle powers' are often responsible for crafting a middle way to bridge conflicting international interests. They typically favour multilateralism and cooperative international behaviour. Middle power diplomacy has played a crucial role in the establishment and maintenance of the nuclear non-proliferation regime. South Africa has played the role of a middle power in nuclear diplomacy since 1994, drawing on its moral position after giving up its nuclear weapons. This role has especially involved joining the efforts of middle powers in the North, such as Norway and Canada, to indefinitely extend the Nuclear Non-Proliferation Treaty (NPT). However, South Africa's foreign policy has shown a gradual shift away from a middle power orientation not least due to an increasing non-aligned position that calls for deep reforms to the perceived unfair world order tilted in the favour of the developed North. This shift is also visible in South African nuclear diplomacy and is eroding the middle ground that has so far sustained the nonproliferation regime. The paper argues that South Africa's middle power diplomacy has allowed it to punch above its weight in the nuclear realm, but its pursuit of international reforms has resulted in the drawing of a fault line between developed and developing countries. It is in the interest of nuclear non-proliferation to regain the middle ground by forming broad coalitions amongst all actors interested in nuclear disarmament.
\end{abstract}

\section{Introduction}

South Africa's foreign policy has typically reflected that of a middle power since its pariah status was overturned in 1994. Middle powers are the 'do-gooders' or 'helpful fixers' in international politics. They construct a role for themselves as mediators in disputes between states, and strongly encourage cooperative behaviour. Middle power diplomacy has played a crucial role in the establishment of the nuclear non-proliferation regime of which the Nuclear Non-Proliferation Treaty 
(NPT), the various nuclear arms reductions treaties, the test ban treaties and the nuclear materials export regulations form the foundations. Having given up its nuclear weapons, South Africa has played the role of a middle power in nuclear diplomacy since 1994, e.g., by calling for the indefinite extension of the NPT at the 1995 NPT Review Conference, at the 2000 Review Conference joining the New Agenda Coalition to present 'Thirteen Practical Steps' to nuclear disarmament and taking the lead in negotiating the Pelindaba Treaty to create an African Nuclear Weapons Free Zone. ${ }^{1}$

However, in the last two years there appears to have been a shift in South Africa's general foreign policy orientation to include revisionist elements. In the sense we use the concept here, revisionism implies efforts of a hard-line nature to transform a perceived power imbalance characterizing the world order. This shift is illustrated in South Africa's voting behaviour as a nonpermanent member of the UN Security Council where it has voted against major Western powers on several occasions and exerted a non-aligned policy orientation. The question that this paper explores is whether this foreign policy shift is also prevalent in South Africa's nuclear diplomacy. If so, it would mean that an important source of middle power diplomacy, keeping the nuclear weapons non-proliferation regime intact, is eroding. The article finally asks what impact losing the middle ground might have for non-proliferation in general and if losing the middle ground spells danger of the non-proliferation regime eroding, how this erosion might be halted and reversed.

\section{What is the middle ground?}

Even though the nature of the international state system can be considered as anarchic due to the absence of a world government, it is apparent from oft-employed terms such as super, great, secondary and small powers that a hierarchy of states exists based on their relative positions vis-à-vis each other in the international distribution of power. Further, viewed from the system level of analysis, ${ }^{2}$ this hierarchical structure has a determining influence on the roles and functions that states perform in the international state system (see Gilboa, 2009). This posits a fundamental, two-sided question regarding the behavioural motivation of states; namely, are the roles and functions of states thrust upon them by virtue of their hierarchical positions, or are they formulated by the states' own self-perceptions a propos their positions in the hierarchical structure? Paraphrasing Schoeman (2003, p. 352), this question assumes particular relevance to the conceptualisation of 'middle power'; namely, who (or what) confers the status of middle power and why? This section argues that the concept of 'middle power' is informed by both system-level considerations of a state's position in the international hierarchy and state-level considerations of a state's own perceptions regarding its identity, roles and functions in the international system of states.

Most international relations theorists attribute some importance, due to the systemic nature, to the number and behaviour of great powers (and especially their 
interaction with each other) in determining the international order, or put somewhat differently, in defining the international system of states (see for example Waltz, 1959). Consequently, great powers are considered to be states whose behaviour condition and shape the 'rules of the game', while conversely, small states have little systemic influence. One interpretation of the 'middle power' concept is therefore that middle powers are states that are neither great nor small, but whose foreign policy behaviour derive from their 'in-between' status and is defined particularly in relation to the great powers (Neack, 2003, p. 163). As noted by Schoeman (2003, p. 350), the traditional conceptualization of middle power thus employed in IR literature does not necessarily connote to the regional position or development levels of middle powers (aspiring or otherwise), but rather emphasises their size, position and rank as determined by the systemic structure resulting from the international distribution of power.

It is the interstices of the international systemic structure that afford states the opportunity to play a certain role or perform certain functions (Spence, 2001). Middle powers cannot influence or direct the international system as the great powers do, nor do they necessarily seek to do so. Instead, middle power diplomacy is characterized by a moral imperative. Middle powers find their niche in seeking to exert a moral influence on the international system and hence are states who pursue the self-identified role of committing 'their relative affluence, managerial skills and international prestige to the preservation of international peace and order' (Neack, 2003, p. 164). Accordingly, middle powers engage in activities such as international mediation, coalition-building, conflict resolution and peacekeeping. In short then, they are the 'go-betweens', 'do-gooders' and 'helpful fixers' of the international system (Neack, 2003, pp. 163-165).

This moral orientation does not, of course, preclude the 'essentially interestbased [and] status seeking' nature of middle power diplomacy (Neack, 2003, p. 165). Cox (1996, p. 243) emphasises the affinity of middle powers to international organization as a process by arguing that a middle power commits itself to the process of developing a stable and more orderly international system precisely because of its interest in such a scenario, which is altogether 'different from seeking to impose an ideologically preconceived world order'. Unable to effectively go it alone to preserve the international norms and principles that underpin the international system, middle powers are therefore inclined to multilateralism: 'to pursue multilateral solutions to international problems, ... to embrace compromise positions in international disputes and ... to embrace notions of "good international citizenship" to guide diplomacy" (Cooper, Higgott and Nossal quoted by Neack, 2003, p. 164). Middle powers, then, exercise international leadership in cooperation with other states or through international organisations by providing technical and entrepreneurial leadership on the specific global issues they choose to resolve on the basis of what 'they feel they can deal with [...] more effectively, and because they cannot or do not wish to challenge the great powers. While great powers can act unilaterally or through coalitions they form and dominate, middle powers need to create partnerships and work through international organizations and forums' (Gilboa, 2009). 
In the aftermath of the Second World War and against the backdrop of unfolding ideological rivalries between the superpowers, states such as Canada, Australia, the Netherlands, and the Scandinavian countries of Sweden, Norway and Denmark thus emerged as the quintessential middle powers of the Cold War international order. Clearly, these traditional middle powers had a final characteristic in common - all were part of the First (or developed) World. However, as the end of the Cold War effected prescient systemic changes to the international order, so did the consequential adjustments to the definition, role and functions of some middle powers necessitate a 'rethink' of the 'middle power' conceptualization. ${ }^{3}$ The term 'emerging middle powers' therefore came to be particularly applied to states such as India, Brazil and South Africa that, unlike the traditional middle powers, are part of the developing world and are big powers in their respective regions.

In further contrast, whereas 'traditional middle powers played their roles on a world scale $[y]$ et ... were always subordinate to or in the direct presence of the superpowers and as interlocutors bridging the space between the powerful and powerless in the international system', the role of 'emerging' middle powers is forged with duality (Schoeman, 2003, p. 351). On the one hand, they are endowed with the apparently specific role of regional leader due to considerations of their economic, military or geopolitical significance and are supported by great powers as such. On the other, and more reminiscent of the traditional middle power role, since their power status may be underpinned by high moral repute, their roles appear to be focused on the pursuit of more extensive functions in the global system (Schoeman, 2003, p. 353; see also Ozkan, 2006). Finally, it is important to note that even though emerging middle powers are often supported and encouraged by great powers in this regard, they are at other times also 'deeply resented, actively opposed, openly criticized and even subjected to threats of punishment' (Schoeman, 2003, p. 354). ${ }^{4}$

\section{South Africa as a reformist middle power: bridge-builder between the 'nuclear haves' and the 'nuclear have nots'}

Following the historic multi-racial democratic elections of 1994, the postapartheid government in South Africa faced the challenge of posturing a 'new' foreign policy that would serve and advance both the country's domestic interests contextualized by the transition to democracy, and its international interests and obligations as a newly welcomed member of the international community. This challenge was further complicated by the high expectations the international community had of South Africa's post-1994 role in the international system. Lacking the capabilities and opportunities as a developing country to unilaterally achieve its foreign policy objectives, South Africa therefore sought to reconcile the potentially divergent demands of this challenge by espousing multilateralism as the central feature of its foreign policy.

South Africa perceived itself as a bridge-builder between the developed and developing states. More specifically, South African diplomacy attached special significance to "multilateral coalition-building among state and non-state actors 
... in a world groping for the re-establishment of order' and accordingly committing itself to 'orderliness and security on interstate relations and facilitating orderly change in the world system' (Taylor, 2006, p. 159). In the words of the then South African foreign minister, Alfred Nzo (quoted by Schoeman, 2003, p. 354), South Africa's objective with multilateral diplomacy was to strengthen a 'rules-based system which limits the possibility of unilateral actions by major powers' and with the practical advantage of providing an opportunity for smaller states 'to participate on equal footing on the world stage'. This pragmatic policy stance based on incremental change indicates what Nel et al. (2001, p. 5) has termed the 'reformist tendency' in South Africa's post-1994 foreign policy, namely, that since Pretoria apparently assumed that the fundamental underpinnings of the global order are not subject to major transformation, South African diplomacy largely adopted a technical perspective or problem-solving approach to multilateralism that is pursued within the perceived constraints operating at the international structural level. Therefore, although South African multilateral diplomacy aimed to "improve"" the world, it is reformist within the limits set for it by the global actors' (Taylor, 2006, p. 160).

It is difficult to identify the exact expectations the great powers had or continue to have of South Africa's role as a middle power in the international system, or similarly to assess the extent to which South Africa had been given free rein in its pursuit of such a role. As Schoeman (2003, p. 354) points out, this appears to vary according to issue area, with South Africa enjoying the largest freedom with regards to arms control and disarmament issues.

South Africa's assumed role as a middle power is a particularly natural and apparent one in the field of nuclear non-proliferation. Having 'committed itself to democracy, sustainable development, social justice and environmental protection' as the cornerstones of its foreign policy, the South African Government 'extended this policy to include the promotion of global peace and security through the elimination and non-proliferation of weapons of mass destruction' as a priority policy issue area (Department of Foreign Affairs, 1995, p. 7). South Africa's nuclear foreign policy was influenced by a number of factors. Firstly, South Africa is the only African country and member of the NonAligned Movement (NAM) that enjoys membership of all the major nuclear non-proliferation regimes, regulating agencies and suppliers groups, such as the Nuclear Non-Proliferation Treaty (NPT), International Atomic Energy Agency (IAEA), Zangger Committee (ZC) and Nuclear Supplier's Group (NSG). An acknowledged possessor of advanced nuclear technologies, South Africa is also recognized as a developed state in the field of nuclear technology. Finally, South Africa's moral stature following the transition to democracy was further enhanced by its unique position as the only state that has voluntarily relinquished its nuclear weapons programme. ${ }^{5}$ Driving its initiatives through multilateral agencies, organisations and institutions, South Africa clearly resolved to take advantage of its position and stature in order to play a leading role in the field of nuclear non-proliferation. In this context, South Africa specifically perceived itself as a bridge-builder between the 'nuclear haves' and the 'nuclear have 
nots', which would 'allow South Africa to promote dialogue and interaction between the developed world on the one hand while, on the other, addressing the concern of the developing world that they will be unable to acquire the technology they need for their development' (Department of Foreign Affairs, 1995, p. 9).

The first opportunity for South Africa to implement its assumed role as bridgebuilding middle power came with the NPT Review and Extension Conference (RevCon) held in New York from 17 April to 12 May 1995. The NPT RevCon carried a high potential for discord, with the nuclear weapons states (NWS) led by the United States that favoured an unconditional, indefinite extension of the NPT, while the non-nuclear weapons states (NNWS) appeared to regard the NPT RevCon as a 'window of opportunity to move the world towards concrete steps regarding nuclear disarmament' and therefore opposed 'any indefinite extension as an implicit recognition of the perpetuation of the existence of nuclear weapon powers' (Taylor, 2006, p. 166).

Pressure from both sides put South Africa in a difficult position. It would be expected that South Africa vote in line with its allies in the NAM position, yet its desperate need for foreign investment and development assistance precluded South Africa from assuming a position that would weaken the strong linkages under construction at the time with the US as the world's leading economic power (see Taylor, 2006, p. 167). South Africa consequently engineered a broad consensus or 'middle ground' by tabling a proposal that the NPT be indefinitely extended, but that two concurrent (though not legally binding) agreements also be adopted. The one would be aimed at strengthening the NPT review and monitoring process, while the other included a declaration of principles calling for a comprehensive ban on nuclear testing by the end of 1996, as well as a commitment to the eventual elimination of nuclear weapons (New York Times, 10 May 1995; Pretoria News, 11 May 1995). The NPT RevCon Assembly's acceptance of the South African proposal was near-universally hailed as a major vindication of South Africa's role as a middle power. As the Business Day (16 May 1995) put it, South Africa 'focused on defining areas on which the maximum number of signatories ... could find common ground', and consequently played the classical middle power role by 'seek[ing] to expand the area of common ground [making] it possible to curtail risk in the management of conflict' (Cox, 1996, p. 244).

In reality, however, by supporting the indefinite extension of the NPT, South Africa's role at the 1995 NPT RevCon contributed to the legitimization of the global nuclear order while having only the semblance of its potential delegitimization. The final agreement did little to challenge the dominant NWS' position in practice, as was illustrated when China conducted nuclear tests within two days of the NPT RevCon's conclusion and France soon after announced that it too would resume testing. South Africa's triumph thus appeared to be what one commentator (Motumi, 1995) described as a 'pyrrhic victory', while others (Taylor and Williams, 2006, p. 12) remarked of South Africa's bridgebuilding role: 'it is noticeable that Pretoria ... played an active role in directing traffic across this bridge [but] that the flow has been primarily in one direction as 
it has persuaded other [developing] states to accept the "global realities" and Northern agendas.'

One should, however, guard against taking too cynical an approach to these events. After all, as Nel, Taylor and van der Westhuizen point out: 'Because the very idea of middle power and bridge-building assumes an established order only within which this role becomes possible, one cannot expect established or emerging middle powers to be agents of major global transformation-such are the structural constraints of a young democracy trying to "punch above its weight" in the multilateral domain' (2001, p. 17). Rather, it thus highlighted the complexities involved in South Africa's attempt to posture a 'new' foreign policy after 1994 that would placate domestic and international constituencies, each with divergent political agendas and expectations (see Taylor and Williams, 2006, p. 11).

Perhaps ironically then, South Africa has since 1995 taken a more activist position in nuclear non-proliferation diplomacy, pushing forward the agenda of disarmament in a process perceived to 'have gone cold' (Taylor, 2006, p. 175). In addition to joining Brazil, Egypt, Ireland, Mexico, New Zealand, Slovenia and Sweden in establishing the New Agenda Coalition (NAC), ${ }^{6}$ South Africa signed and ratified the Comprehensive Test Ban Treaty (CTBT) after having been substantially involved in the CTBT resolution process as a member of the core management group, and intensified its leading efforts to establish an African Nuclear Weapons-Free Zone based on the provisions of the 1996 Pelindaba Treaty. Ahead of the 2000 NPT RevCon, South Africa again played a leading and active role in the Preparatory Commissions (PrepComs), asserting that '[w]e are tasked [at the RevCon] to ensure that the bargain that was struck in 1995, and that provided the basis and the rationale for the agreement to extend our Treaty indefinitely, is met and fully implemented' (Minty, 2000). In this context, the NWS 'should make an unequivocal undertaking to accomplish the total elimination of their nuclear arsenals' as a first step 'on the pathway to nuclear disarmament' (Minty quoted by Taylor, 2006, pp. 175-176).

According to Taylor (2006, pp. 176-177), South Africa's increasing activism vis-à-vis nuclear disarmament and evidently more hostile tone regarding the NWS can to a large extent be explained as a reaction against criticism that South Africa betrayed its developing state and NAM allies by supporting the NWS position for the indefinite extension of the NPT at the 1995 RevCon, and was subsequently duped by the NWS. Such a stance would appear to have the aim of demonstrating that South Africa is not merely a lackey of the NWS (particularly the United States), while 'appearing to challenge and confront the dominant powers over nuclear weapons after the NPT [had] been indefinitely extended throws up the imagery of autonomy in which a country such as South Africa can challenge the developed world' (Taylor, 2006, p. 177).

Given that South Africa has 'helped [to] craft and deliver' the scenario in which the indefinite extension of the NPT provides little room for holding the NWS accountable to the disarmament provisions of the Treaty, its more activist nuclear diplomacy since 1995 would appear to be 'devoid of any real substance' 
since it 'lacks any potency to seriously undermine the existing nuclear orderrhetoric against NWS intransigence over disarmament notwithstanding' (Taylor, 2006, p. 177). In recent years, however, several subtle signs have emerged that may indicate a shift in South Africa's nuclear diplomacy from reformism to revisionism.

\section{Shift from reformism to revisionism in South African foreign policy}

Said et al. (1995, pp. 34-35) distinguish between two types of foreign policy, namely a policy of the status quo and a policy of revisionism. ${ }^{7}$ Status quo foreign policies give 'expression to a basic satisfaction and wish to conserve the contemporary pattern of international relations and the state's place in it'. This does not mean contentment with all aspects of the international order or resistance to change per se. Rather policymakers hold a perception that the system is as advantageous to their own state as they can reasonably hope for. Revisionism, on the other hand, 'flows from either a rejection of the current status and role of the state in the system or rejection of the structure and dominant values of the system itself' (Said et al., 1995, p. 35). Although various revisionist foreign policies can be identified (for example, transformative, subversive or revolutionary), generally revisionism manifests as follow in foreign policies (Said et al., 1995, p. 36):

- Strategic offensiveness to modify the international environment to correspond with decision-makers' idea of a favourable order;

- Resistance toward measures that may inhibit freedom of action to seek change;

- Acceptance of tension and even active pursuit of conflict (including war) to effect desired change; and

- A willingness to take risks and daring behaviour in the face of possible costs.

Although South Africa's post-1994 foreign policy has, as mentioned above, portrayed a reformist character, there seems to have been a shift from its initial idealism that South Africa can effect change (such as reform of the UN Security Council or a better dispensation for developing countries at the World Trade Organization) through multilateral forums and a rules-based international system of equals. Instead, idealism has been replaced with suspicion typical of realpolitik and characterized by elements of revisionism in South Africa's foreign policy.

A critical moment that prompted this revisionism was the US invasion of Iraq. Former President Thabo Mbeki took a strong stance against the war. In the run-up to the invasion there was a South African team of weapons experts in Iraq to share South Africa's experience in nuclear disarmament with the Iraqis in an effort to prevent a war (Cobb, 2003). In this period the Bush administration tried to legitimize the invasion by building a case for war and garnering international support, not least through an economic 'carrot and stick' approach (Barns, 2003; Cobb, 2003). Mbeki not only vocalized his opposition to the war at forums, such as the UN, the NAM, the African Union (AU) and through media briefings by his presidential spokesperson and the Department of Foreign Affairs at home, but was 
instrumental to an AU resolution that opposed the war. Mbeki actively lobbied the three African states that filled non-permanent seats at the UNSC at the time (Angola, Cameroon and Guinea) to vote against a UNSC resolution that would have authorized the US invasion (Barns, 2003). This resolution was introduced by the US, UK and Spain and was subsequently withdrawn when it became clear that it would not pass. The realization that the war would go ahead without UNSC backing was for the South African government a 'blow to multilateralism' and 'an unfortunate precedent' in dealing with world affairs (Polity, 2003, http://www.polity.org.za/article/iraq-war-a-blow-to-multilateralism-mbeki2003-03-20).

Although major Western powers, such as Germany and France, also vocally opposed the invasion of Iraq, fewer middle powers did so, for example both Australia and the Netherlands contributed troops. Canada, another traditional middle power, did not join the 'coalition of the willing', but did not actively seek to influence other states to take a stand against the war either. Canada also later joined the reconstruction efforts and training of police in Iraq. From the Mbeki administration's response to the war, it is fair to deduce that South African officials experienced the Iraq invasion as confirmation of the realist logic of world politics. Moreover, this realization resonated with an existing worldview that interprets power politics through the lens of non-alignment. Whereas other Western states viewed the US invasion of Iraq without UNSC backing as unfortunate unilateralism, for the Mbeki administration it was all too reminiscent of Western imperialism. Anti-imperialism, according to Nathan (2008, p. 2), characterizes the ruling African National Congress's (ANC's) history and ideology and is therefore strongly evident in South Africa's foreign policy. Anti-imperialism sets South Africa apart from Western countries despite South Africa's liberal constitution and democratic politics. The Iraq invasion ignited a revisionist form of non-alignment that would become pronounced when South Africa held a non-permanent UNSC seat in 2007 and 2008.

During this period South Africa voted against the Western powers on the Council on several occasions, inviting criticism from these powers and other international and South African actors. One of the most notorious cases was South Africa's vote against the draft resolution on Myanmar/Burma introduced by the US and the UK (UN Doc/2007/14). The resolution called on the military junta to cease military attacks and human rights abuses, and to allow freedom of expression and democratization. Despite expressing concern about the situation in Myanmar, South Africa argued that the resolution would compromise the good offices of the secretarygeneral in the matter, that the Charter mandate of the UNSC is to deal with threats to international peace and security and that human rights abuses in Myanmar do not constitute such a threat and that the issue would be better addressed by the Human Rights Council. Both Russia and China voted against the resolution too, so technically South Africa could have abstained, as this double veto would have meant that the resolution would not pass in any event. South Africa could therefore have saved itself much criticism and controversy. 
Many critics argued that South Africa adopted an overly legalistic or technical approach and that the abuses in Myanmar warranted the only UN organ with enforcement powers to act. The fact that South Africa chose to vote 'on principle' against the resolution, and thereby against the wishes of two major Western powers, should be viewed in the context of a perceived abuse by the great powers of international institutions to impose their will on smaller states. Dire Tladi (2006, p. 231), the Principal Advisor for International Law for the South African Department of Foreign Affairs, argues for example: 'In order to promote the rule of law, all subjects and organs of international law must be bound by rules of the legal system and none can be allowed to operate above the legal system. One way that the Security Council can be held accountable for its use of power, is through constant scrutiny by observers.' Tladi (2008, pp. 29-30) goes further, to note that the predominance of the five permanent members in the Council, its working methods and lack of a legal culture (presumably because political considerations generally overshadow legal considerations), are all reasons to interpret the powers of the Council restrictively. This is not based on narrow legalistic or technical grounds, but 'on moral notions of legitimacy and democracy'. South Africa's vote thus resulted from its view that the UNSC has become a tool for great powers to play the role of world government, an unelected world government at that.

In a report produced by the Austrian government in preparation for Austria's non-permanent membership starting in 2009, similar concerns about the UNSC and the rule of law in international politics are expressed. However, the Austrian government's approach in addressing these concerns seems to retain its middle power orientation, concluding that the Council is 'an extraordinarily powerful instrument for promoting the rule of law at both national and international levels, but this is more legitimate and most effective when the council submits itself to the rule of law' (Chesterton, 2009).

The different approach is perhaps best explained by referring to another case in which South Africa would seem to be defying its own human rights stance in favour of righting perceived bias (and power imbalance) in international politics, the International Criminal Court (ICC)'s charging of President Omar Al-Bashir of Sudan for war crimes in Darfur. The ICC has issued arrest warrants for 13 people since its formation in 2002. All of these are for African leaders. Its investigation of Al-Bashir despite Sudan (like the US) not having acceded to the Rome Statute stems from a UNSC Resolution (1593 of 2005) that referred the situation in Darfur to the ICC prosecutor. Former South African President Thabo Mbeki has argued that Al-Bashir is a victim of selective prosecution-an understandable position when atrocities in the Iraq War (and its legality), and breaches of international law associated with the Abu Ghraib prison and the Guantanamo Bay detention centre remain uninvestigated (Laurence, 2009). In fact, it is unimaginable that these situations would be referred to the ICC prosecutor by the UNSC with the US and two of its NATO allies holding three vetoes. Justice applied in accordance with international law seems not to be blind, but applied with the prejudice of geopolitics in mind. Laurence (2009) writes: 'it would help if the 
ICC showed a greater willingness to exercise its prosecutorial prerogatives beyond Africa'. It should be noted, however, that, bar the Sudanese case, all the other cases where the ICC has issued arrest warrants have followed referrals of situations to the ICC by African governments (Uganda, Central African Republic and the Democratic Republic of the Congo). Nevertheless, as was the case with the Burma/Myanmar vote, the perceived unfair application of international law leads South Africa to question international bodies, such as the ICC and the UNSC, even when they are pursuing worthy goals, such as human rights (Sunday Independent, 15 March 2009). This has a polarizing effect on international relations, contradicting South Africa's middle power orientation.

Much of the shift in South Africa's foreign policy is related to its selfidentification as an 'emerging' power and siding with NAM. Non-alignment was a position adopted by Third World states in the $1950 \mathrm{~s}$ onwards to promote their autonomy during the Cold War, sometimes to play off the East and West against each other and to pursue independent development in the aftermath of colonization. Amidst the idealism of the immediate post-Cold War period, it looked as if new relationships between developed and NAM countries could evolve. In fact, when South Africa assumed the NAM presidency in 1998, the Group of 8 (developed) countries previously unfavourably disposed to NAM were invited to participate as guests for the first time in a NAM Summit hosted by South Africa in Durban in 1998 (Cherian, 1998). This effort to bring developed and developing countries together is again illustrative of South Africa's middle power role during that period. However, the failure to make headway in international forums on fair trade, development and UN reform have brought a sense of disillusionment to NAM.

With the rise of China during the past two decades and its increasing economic involvement in many African countries in search for food and energy security, there seems to be resurgence in a non-aligned position reminiscent of the Cold War on the continent. The sense exists that through South-South cooperation (e.g., India-Brazil-South Africa (IBSA)) and support from China, developing countries have more bargaining power vis-à-vis developed states. South Africa in particular has expressed its discontent with the power imbalance in the world order and the (ab)use of multilateral institutions by major powers to perpetuate/ sustain the unfair distribution of power (Pretorius, 2008; see also Financial Express, 17 July 2007, http://www.financialexpress.com/old/latest_full_story. php?content_id=170297).

In trade relations, South Africa has been vocally opposing the European Union's Economic Partnership Agreements (EPAs) with its neighbouring states, risking souring SA-EU relations. The margin of South Africa's emerging middle power diplomacy has thus expanded beyond reformism to include revisionist elements, such as efforts to restrict a liberal interpretation of the UNSC mandate in order to secure sovereignty for smaller states, occasional hard-line rhetoric against major Western powers and the acceptance of risks that may have costs in other diplomatic areas. This assertive non-aligned position explains what baffled Western commentators have referred to as 'rogue' behaviour in South 
African foreign policy, from being supportive of the Mugabe regime to denying the Dalai Lama a visa to attend a peace conference (Washington Post, 15 April 2008, http://www.washingtonpost.com/wp-dyn/content/article/2008/04/14/ AR2008041402638.html; Kirkchick, 2009; see also Nathan, 2005).

\section{Revisionism in South Africa's nuclear diplomacy}

South Africa's concern that international law is being applied selectively and that multilateral institutions are being abused by major powers to maintain the balance of power in their favour also extends to the nuclear realm. This was most evident in the amendments that South Africa insisted on before it agreed to vote for Security Council Resolution 1747 (2007), the second Chapter 7 resolution that imposed sanctions against Iran. These amendments were referred to by the US Under-secretary for Political Affairs at the time, Nicholas Burns, as 'killer amendments ... that would have ripped apart the P-5 resolution' (US State Department, 2007). South Africa brought these amendments to the table on the basis of its non-aligned foreign policy, this time despite the fact that China and Russia had agreed to vote for the resolution. From the amendments it is clear that South Africa wanted to ensure that Resolution 1747 did not lead down the same path that led to the invasion of Iraq in 2003.

The South African amendments that were accepted included a sunset clause for sanctions as soon as Iran complied with the IAEA and UNSC requirements, language in the resolution that recognized the IAEA as the 'sole internationally recognised body dealing with verification and monitoring issues', appending the offer of the P5 and Germany for negotiations to the resolution, and appending the full IAEA report that highlighted the positive and negative findings on Iran to the resolution. The amendments that were not taken on board included a 'time-out' period of 90 days for further negotiation as well as directing sanctions solely at Iran's nuclear programme and not broadly to its arms sales. It thus also seems that South Africa did not want the UNSC resolution to link Iran's nuclear programme to its supposed support of organizations on the US list of terrorist organisations.

The proposed amendments also manifested a deeper perception by South Africa's nuclear diplomats about the current non-proliferation regime. Ambassador Abdul Minty (2007), South Africa's representative on the IAEA Board of Governors, offered the following view when he was asked about South Africa's vote on the resolution by an opposition member in South Africa's Parliament:

The NPT therefore provides a comprehensive set of inter-linked and mutually reinforcing rights and obligations to which the Parties to the Treaty have committed to under the three pillars of the Treaty, namely nuclear non-proliferation, nuclear disarmament and the peaceful uses of nuclear energy ... These rights and obligations are equally binding on all Parties to the Treaty. However, there seems to be an increasing tendency by some Parties to the NPT to focus exclusively on the non-proliferation provisions to the detriment of the nuclear disarmament obligations as contained in Article VI of the Treaty and the provisions pertaining to the peaceful application of nuclear energy. South Africa has therefore 
continued to call for the balanced implementation of all the provisions of the Treaty and, together with its partners in the New Agenda Coalition (Brazil, Egypt, Ireland, Mexico, New Zealand, Sweden and South Africa) expressed its deep concern over the lack of real progress towards nuclear disarmament and the elimination of all nuclear weapons.

Although South Africa thus voted for the resolution eventually, it insisted on amendments despite P5 agreement and amidst vocal concern about the way the NPT was being implemented.

A second illustration of revisionist manifestations in South Africa's nuclear diplomacy was South Africa's strong support for normalization of nuclear trade with India both bilaterally and within the Nuclear Suppliers Group (NSG), an international forum of nuclear technology-exporting countries that determine the guidelines for nuclear exports (Mail \& Guardian Online, 6 October 2006, http://www.mg.co.za/articlePage.aspx ?articleid=285986\&area=/insight/ insight_national/). Because India did not accede to the NPT and tested nuclear weapons in 1974 and 1998, international restrictions were placed on trade in nuclear technology with that country. In 2005, then US President George W. Bush and Indian Prime Minister Manmohan Singh announced a cooperation deal that also included nuclear energy and trade in this area.

This dimension of the agreement was controversial as it would have legitimized India's acquisition of nuclear weapons and in a de facto manner have recognized the country as a nuclear weapons state with similar privileges to NWS within the NPT framework. Non-proliferation activists interpreted this as rewarding bad behaviour and watering down one of the main incentives for NNWS to join the NPT and abide by the requirement not to obtain nuclear weapons, namely access to civilian nuclear technology (Bajoria \& Pan, 2008). India decided to remain outside the NPT and to develop nuclear weapons and is therefore not entitled to nuclear technology. Moreover, at the time, India's civilian and military facilities were not clearly separated and civilian nuclear trade could have ended up boosting India's military programme, possibly aggravating the Indo-Pakistani conflict.

Although it can be argued that South Africa's support for normalization of nuclear trade with India in this instance confirmed the US position and would thus not be revisionist, South Africa's position veered from a principled non-proliferation stance (previously based on a moral imperative). In fact, South Africa's support of India, it is argued here, had little to do with support for the US. Rather its position can be explained in terms of South-South cooperation within the India-Brazil-South Africa (IBSA) forum context. In addition, India is perceived as a fellow NAM member, an important economic partner and an 'old friend'. South Africa's High Commissioner to India, Francis Moloi, admitted as much when he said in 2006: 'We can't change the rules of NPT for the world but between friends, you can be sure that issues will be looked at like friends' (Rediff India Abroad, 2006, http://www.rediff.com/news/2006/sep/24ndeal. $\mathrm{htm})$. There is a sense that South Africa compromised its moral high ground that served as the foundation of its middle power diplomacy in the nuclear nonproliferation realm. Alternatively, within a non-aligned and South-South 
cooperation context its support would be in line with efforts to change the balance of power from North-South imbalance and therefore mean that South Africa reinterpreted its moral high ground to suit its revisionist outlook in this case.

A third illustration of revisionism in South Africa's nuclear diplomacy is drawn from statements by Ambassador Abdul Minty during his campaign to succeed Mohamed ElBaradei as IAEA director-general. He emphasised the need for increased 'no strings attached' funding for the IAEA to keep its technical expertise independent: 'IAEA staff must be given the space and time to test and process information. This is the rock foundation of the IAEA's integrity. This cannot be decided by governments' (The Star, 12 February 2009). In fact, his campaign and the outcome of the vote very much reflected the broader power relations in world politics. Although Minty was favoured by many in the non-proliferation community, the US-backed candidate, Ambassador Yukiya Amano from Japan, was eventually elected in the sixth round of voting. After the first dead-locked vote, Minty (2009) stated: 'We were hopeful that those that advocated change and a relationship with the developing world based on trust and partnership would - in this important election process-have implemented these noble ideals, but sadly it appears as this has only remained as good intentions.' $\mathrm{He}$ then proceeded to quote Martin Luther King: 'Change does not roll in on the wheels of inevitability, but comes through continuous struggle. And so we must straighten our backs and work for our freedom. A man can't ride you unless your back is bent', saying that King inspired South Africa's struggle against apartheid. Although he confirmed South Africa's non-proliferation stance, this was done with the call to vigilance 'that developing countries are not denied access to the benefits of nuclear energy and advanced technologies needed for their own development'.

From his statements it is clear that the underlying premise in South Africa's nuclear diplomacy is no longer that of a do-gooder or helpful fixer, but rather deep distrust of the NWS and the Western NWS (and their allies) in particular. The disillusionment that these states are not keeping to their end of the nonproliferation bargain is palpable. The strong choice of the word 'struggle' in this context conveys a sense that we will see more reformist behaviour from South Africa and very likely an increase in revisionist rhetoric.

\section{Conclusion: implications for nuclear non-proliferation}

At the time of writing (late 2009) the official South African position is still committed to non-proliferation. However, just as the Myanmar/Burma vote and the Al Bashir case pitched human rights against South Africa's perception of selective application of international law, the likelihood exists that a similar trade-off between non-proliferation and non-alignment may occur. South Africa may become guilty of taking decisions on nuclear matters in accordance to its aversion to power imbalances in the non-proliferation regime, rather than on the basis of principled non-proliferation as such. Already, South Africa's stance on the Iran vote has been seen by the P5 as detracting from the united front that they wanted to construct to curb Iran's 
nuclear programme. So too did South Africa's support for normalization of nuclear trade with India draw criticism from the non-proliferation community. The revisionist elements in South Africa's nuclear diplomacy may also alienate it from other middle powers and perpetuate a rift between developed and developing countries in their efforts to sustain the non-proliferation regime.

This article proposes that an eroding of the middle ground is not in the interest of non-proliferation. This erosion takes place when NNWS' positions become polarized and the moral imperative of non-proliferation becomes compromised. If the aim is complete nuclear disarmament, the fault-line would be better defined as being between NWS and NNWS than between developed and developing countries. South Africa could marginalize itself in the realm of nuclear diplomacy by withdrawing to a hardline non-aligned position, thereby limiting the scope of diplomatic manoeuvre available to it. A revisionist stance against NWS could undermine the non-proliferation regime as such and may simply lead to diplomatic stalemate. It is important for South Africa to continue to work with likeminded states outside NAM too to form a united call for NWS to give up their nuclear weapons.

A middle power identity is as much conferred by the external environment as it is a self-identification. If officials in Western NNWS, such as Norway, Germany and the Netherlands, want South Africa to continue to play a middle power role, they need to show a greater appreciation of South Africa's past efforts and the nonaligned position in general. This may require them to break ranks with 'nuclear have' states that are allies in other areas of their foreign policies, to form common positions with NAM states. For example, if they had voted together for an IAEA director-general, even though the candidate was not supported by the US, it might well have restored the trust of non-aligned states in a common non-proliferation project and reversed a conflict of moral and the political imperatives. President Obama has committed the US under his administration to the NPT and to work towards the elimination of nuclear weapons (e.g. Obama, 2009). Although rhetorical at this point, his commitment has unleashed similar pro-disarmament statements and actions from other leaders and high profile individuals (e.g. the European Parliament's approval of measures to achieve a nuclear weapons free world by 2020). Obama's commitment thus presents new opportunities for nuclear disarmament, not least to mobilise a less obstructionist discourse from the US and NWS during the NPT preparation and review conferences.

\section{Notes}

*Department of Political Sciences, University of Pretoria, South Africa. Email: rianleith@gmail.com

**Department of Political Studies, University of the Western Cape, South Africa. Email: jpretorius@uwc.ac.za The authors are associated with the Pugwash Conferences on Science and World Affairs.

1. The Pelindaba Treaty has since entered into force-a feather in the cap of the South African government and the non-proliferation community in that country (Broodryk and Stott, 2009).

2. From a state-centric approach, the system level of foreign policy analysis focuses on how a state's foreign policy behaviour is influenced by the international system of states.

3. See Neack (2003, p. 166): 'Middle power studies all have emphasised middle power vulnerability to changes in the central great power relationship. The central great power relationship defines the system, and establishes 


\section{R. LEITH AND J. PRETORIUS}

the range for permissible actions particularly for states closest to the top. Middle powers understand this constraint and carefully negotiate their own positions and behaviours within the tolerable range. As the central relationship changes, so too do the possible roles and behaviours of the middle powers.'

4. South Africa's relations with states such as Cuba and Libya, its participation in the 1998 Operation Boleas in Lesotho, and its handling of the crisis in Zimbabwe are prominent examples here.

5. South Africa embarked on a nuclear weapons programme in 1970 and constructed its first nuclear device in 1977. Between 1981 and 1989, South Africa constructed six nuclear weapons, with a seventh nearing completion when President F.W. de Klerk shut down the programme in November 1989 and ordered all seven devices to be destroyed. On 10 July 1991 South Africa acceded to the NPT and in September of the same year accepted IAEA inspections and monitoring of its nuclear facilities.

6. The NAC is an initiative of middle-ranking powers that calls on NWS to commit themselves to the elimination of their nuclear weapon arsenals

7. 'Revisionism' here should not be understood in the historiographical sense to mean the reinterpretation of conventionally held views of historical events. Rather, the term revisionism is used in this article to mean a foreign policy that asserts growing discontent with the current structure of international relations and a desire to assertively right perceived wrongs.

\section{References}

Bajoria, J. and Pan, E. (2008), 'The US-India Nuclear Deal', Council on Foreign Relations Backgrounder. Available online at: http://www.cfr.org/publication/9663/ (accessed 9 September 2009).

Barns, G. (2003), 'John Howard Should Follow Thabo Mbeki If He Wants To Show Leadership'. Online opinion, 27 March. Available online at: http://www.onlineopinion.com.au/view.asp? $\operatorname{article}=248 \&$ page $=0$ (accessed 7 September 2009).

Broodryk, A. and Stott, N. (2009), 'Africa Is Now Officially a Zone Free of Nuclear Weapons', ISS Today, 12 August. Available online at: http://www.issafrica.org/index.php?link_id=5\&slink_id=8113\&link_ type $=12 \&$ slink_type $=12 \&$ tmpl_id=3 (accessed 7 September 2009).

Cherian, J. (1998), 'New Moment for NAM', Frontline, 15(19), pp. 12-15.

Chesterton, S. (2009), The UN Security Council and the Rule of Law. Final Report and Recommendations from the Austrian Initiative, 2004-2008 (Vienna: Federal Ministry for European and International Affairs).

Cobb, C. (2003), 'Africa: Washington Lobbies for Africa's UN Council Votes', AllAfrica.com, 26 February. Available online at: http://allafrica.com/stories/200302260001.html (accessed 7 September 2009).

Cox, R.W. (1996), Approaches to World Order (Cambridge: Cambridge University Press).

Department of Foreign Affairs of the Republic of South Africa (1995), South Africa's Policy On The NonProliferation Of Weapons Of Mass Destruction: The Role of the Department Of Foreign Affairs (Pretoria: South African Communication Service on behalf of the Department of Foreign Affairs).

Gilboa, E. (2009), 'Navigating the Middle: The Public Diplomacy of Middle Powers', Public Diplomacy Magazine. Available online at: http://publicdiplomacymagazine.com/navigating-the-middle/the-publicdiplomacy-of-middle-powers/ (accessed 2 December 2009).

Kirchick, J. (2009), 'State of Desperation: Why is South Africa, Our Most Stalwart Ally in all of Africa, Acting like a Rogue State?' Newsweek, 11 August. Available online at: http://www.newsweek.com/id/211408 (accessed 11 September 2009).

Laurence, P. (2009), ICC 'selectiveness' does not absolve al-Bashir, Business Day, 14 March 2009. Available online at: http://www.businessday.co.za/weekender/article.aspx?ID=BD4A958991

Minty, A.S (2000), 'Statement to the NPT 2000 Review Conference by H.E. Mr A.S. Minty, Deputy DirectorGeneral Multilateral Affairs, South Africa, New York, 24 April 2000'. Available online at: http://www. nuclearfiles.org/menu/key-issues/nuclear-weapons/issues/proliferation/south-africa/2000-04-24_abduls-minty-npt-opening-statements.htm (accessed 9 April 2009).

Minty, A.S. (2007), 'Which Amendments Proposed By South Africa With Regard To Measures Against Iran In Connection With Its Development of Nuclear Technologies'. Written reply to question No. 698 in the National Assembly. Internal question paper, No. 15, 18 May.

Minty, A.S. (2009), 'Statement by Ambassador Abdul Samad Minty, South Africa's Governor to the IAEA Board of Governors at the IAEA Board of Governors Meeting', Vienna, 27 March 2009.

Motumi, T. (1995), 'South Africa and the Nuclear Non-Proliferation Treaty - Diplomatic Coup or Pyrrhic Victory?', African Security Review, 4(2), pp. 46-51.

Nathan, L. (2005), 'South Africa: A Coherent Foreign Policy-Most of the Time'. International Affairs, 81(2), pp. 361-372 
Nathan, L. (2008), 'Anti-imperialism Trumps Human Rights: South Africa's Approach to the Darfur Conflict', Crisis States Working Papers (Crisis States Research Centre, London School of Economics), 2(31), pp. 1-13.

Neack, L. (2003), The New Foreign Policy: US and Comparative Foreign Policy in the 21st Century (New York: Rowman \& Littlefield).

Nel, P., Taylor, I. and van der Westhuizen, J. (2001), 'Reformist Initiatives and South Africa's Multilateral Diplomacy: A Framework for Understanding', in: P. Nel, I. Taylor and J. van der Westhuizen (eds), South Africa's Multilateral Diplomacy and Global Change: The Limits of Reformism (Aldershot: Ashgate).

Obama, B.H. (2009), Remarks delivered in Hradcany Square, Prague, Czech Republic, 5 April. Available online at http://www.whitehouse.gov/the_press_office/Remarks-By-President-Barack-Obama-In-Prague-AsDelivered (accessed 24 February 2010).

Ozkan, M. (2006), 'A New Approach to Global Security: Pivotal Middle Powers and Global Politics', Perceptions: Journal of International Affairs, Spring 2006. Available online at: http://papers.ssrn.com/sol3/ papers.cfm?abstract_id=1434768 (accessed 2 December 2009).

Pretorius, J. (2008), 'Non-alignment in the Current World Order: The Impact of the Rise of China', Strategic Review for Southern Africa, 30(1), pp. 1-27.

Said, A. et al. (1995), Concepts of International Politics in Global Perspective, 4th edn (Englewood Cliffs, NJ: Prentice Hall)

Schoeman, M. (2003), 'South Africa as an Emerging Middle Power: 1994-2003', in: J. Daniel, A. Habib and R. Southall (eds), State of the Nation: South Africa 2003-2004 (Pretoria: HSRC Press)

Spence, J.E. (2001), 'Introduction', in: J. Broderick, G. Burford and G. Freer (eds), South Africa's Foreign Policy: Dilemmas af a New Democracy (London: Palgrave).

Tladi, D. (2006), 'Reflections on the Rule of Law in International Law: The SC, International Law and the Limits of Power', South African Yearbook of International Law, 31, pp. 231-243.

Tladi, D. (2008), 'Strict Positivism, Moral Arguments, Human Rights, and the Security Council: South Africa and the Myanmar Vote', African Human Rights Law Journal, 8(1), pp. 23-36.

Taylor, T. (2006), 'South Africa and the Nuclear Non-Proliferation Treaty', in: D. Lee, I. Taylor and P.D. Williams (eds), The New Multilateralism in South Africa's Diplomacy (London: Palgrave).

Taylor, I. and Williams, P.D. (2006), 'Understanding South Africa's Multilateralism', in: D. Lee, I. Taylor and P.D. Williams (eds), The New Multilateralism in South Africa's Diplomacy (London: Palgrave).

US State Department (2007), 'Conference Call on the UNSC Vote on the Iran Resolution (media briefing)', 24 March. Available online at: http://vienna.usmission.gov/sp_unsc_vote.html (accessed 5 March 2009).

Waltz, K.N. (1959), Man, the State, and War: A Theoretical Analysis (New York: Columbia University Press). 